\title{
Modified BEAC conditioning regimen with idarubicin followed by autologous hematopoietic stem cell transplantation is safe and effective for invasive B-cell non-Hodgkin's lymphoma patients
}

\author{
Yueyang Li \\ tianjin tumor hospital \\ Yafei Wang \\ Tianjin Tumor Hospital \\ Su Liu \\ Tianjin Tumor Hospital \\ Zehui Chen \\ Tianjin Tumor Hospital \\ Yizhuo Zhang \\ Tianjin Tumor Hospital \\ Yong Yu \\ Tianjin Tumor Hospital \\ Hongliang Yang \\ Tianjin Tumor Hospital \\ Haifeng Zhao \\ Tianjin Tumor Hospital \\ Zhigang Zhao \\ Tianjin Tumor Hospital \\ chen tian ( $\nabla$ tcgirl2001@sina.com ) \\ Tianjin Tumor Hospital https://orcid.org/0000-0002-0995-990X
}

Research article

Keywords: Idarubicin, autologous hematopoietic stem cell transplantation, Non-Hodgkin's lymphoma

Posted Date: January 17th, 2020

DOI: https://doi.org/10.21203/rs.2.21109/v1

License: @ (i) This work is licensed under a Creative Commons Attribution 4.0 International License. Read Full License 


\section{Abstract}

High-dose chemotherapy (HDC) followed by autologous hematopoietic stem cell transplantation (ASCT) is still a consolidation treatment choice for relapsed/refractory (R/R) B-cell Non-Hodgkin's lymphoma (NHL) patients and some aggressive B-cell NHL as frontline therapy. Due to the shortage of carmustine, we switched to idarubicin-substituted BEAC (IEAC). We compared the outcomes of $72 \mathrm{~B}$-cell NHL patients treated with IEAC or BEAC regimens followed by ASCT. The median time to neutrophil and platelet reconstitution showed no difference between IEAC and BEAC groups. IEAC regimen was well tolerated without increase of adverse events. Transplant-related mortality didn't occur. The overall survival (OS) and progression-free survival (PFS) of IEAC group were a little longer than that of BEAC group. 2-year OS and PFS rate were higher in IEAC group compared to BEAC group. Multivariate analysis showed that AnnArbor staging, IPI score, lactate dehydrogenase $(\mathrm{LDH})$ level, remission of disease, modified regimen were related with the prognosis. In conclusion, IEAC regimen was well tolerated and replacement with idarubicin could effectively prolong the survival of patients.

\section{Introduction}

Non-Hodgkin lymphoma (NHL) is the most common hematologic malignancy [1]. High-dose chemotherapy (HDC) followed by autologous hematopoietic stem cell transplantation (ASCT) has been a standard front-line consolidation therapy for patients with aggressive NHL for decades [2-4], which can eliminate the residual tumor cells, thereby decrease the probability of disease recurrence and prolong the survival [5]. BEAM (carmustine, etoposide, cytarabine, and melphalan), BEAC (carmustine, etoposide, cytarabine, cyclophosphamide) and CBV (carmustine, cyclophosphamide, and etoposide) are the most commonly used regimens for $\mathrm{NHL}[6-7]$.

With the aim of obtaining a higher anti-lymphoma activity and/or reducing the toxic effects, a number of studies suggested the possibility of improving the outcomes of NHL patients through modifing the conditioning regimens [8-10]. BuCyE (busulfan, cyclophosphamide, and etoposide) [11, 12] and Benda-EAM (bendamustine, etoposide, cytarabine, and melphalan) [13-14] were approved to be effective and safe for NHL patients [15-16]. However, idarubicin, which was a widely used anthracycline drug for NHL patients, was rarely reported to be added in conditioning regimen. In 1997, Engert et al found that IIVP (ifosfamide, idarubicin, and etoposide) was a salvage regimen with acceptable toxicity and highly effective for patients with R/R NHL [17]. Due to the shortage of carmustine, bendamustine and nimustine in China, we aimed to examine conditioning with idarubicin and to compare the efficacy and toxicity between BEAC and idarubicinsubstituted BEAC (IEAC).

\section{Methods}

\section{Patients}

This study was subject to approval by the Research Ethics Committee of Tianjin Medical University Cancer Institute and Hospital. All methods were carried out in accordance with relevant guidelines and regulations. Informed consent was obtained from all subjects or, if subjects were under 18, from a parent and/or legal 
guardian. A retrospective study of 72 invasive B-cell NHL patients (18 years old $\leq$ patients $\leq 65$ years old) were enrolled from Jan 2015 to Jun 2018. Patients were divided into two groups randomly, one group received IEAC $(n=40)$, the other group received BEAC $(n=32)$, as shown in Fig. 1. All patients received standard induction chemotherapy and performed ${ }^{18}$-fluorodeoxyglucose positron emission tomography/computed tomography (PET-CT) to evaluate remission state before ASCT (Fig. 1).

\section{Treatment Protocols}

Patients were treated with either the BEAC regimen consisting of Carmustine $\left(300 \mathrm{mg} / \mathrm{m}^{2}\right.$ on day -6$)$, Etoposide ( $100 \mathrm{mg} / \mathrm{m}^{2}$ every 12 hours on days -5 to -2$)$, Cytarabine ( $200 \mathrm{mg} / \mathrm{m}^{2}$ every 12 hours on days -5 to -2$)$, and Cyclophosphamide $\left(1.5 \mathrm{~g} / \mathrm{m}^{2}\right.$ on days -5 to -2$)$ or the IEAC conditioning regimen, with substitution of $\mathrm{BCNU}$ with Idarubicin $\left(8 \mathrm{mg} / \mathrm{m}^{2}\right.$ on days -9 to -7 .).

\section{Study Endpoints}

The follow-up deadline was 01 Oct 2019. The primary endpoint of this analysis was overall survival (OS) among the different conditioning regimens. Secondary endpoints included transplant-related mortality (TRM), relapse or progression, and progression-free survival (PFS). According to WHO criteria, the therapeutic evaluation was divided into complete response (CR), partial response (PR), stable disease (SD) and progressive disease $(\mathrm{PD})$. Neutrophil and platelet engraftment were defined as absolute neutrophil count $>0.5$ $\times 10^{9} / \mathrm{L}$ and untransfused platelet count $>20 \times 10^{9} / \mathrm{L}$, respectively. Toxicity was assessed using the National Cancer Institute Common Terminology Criteria, version 4.0.

\section{Statistical Analysis}

Statistical analysis was performed using SPSS. OS was calculated from the date of diagnosis until death, or until the last follow up date the patient was known to be alive. PFS was determined for responders from the time of diagnosis until disease progression, relapse, death, or until last follow up. TRM was defined as any death without recurrent lymphoma. The significance of difference between survival curves was calculated by the log-rank test. Groupwise comparisons of the distributions of variables were performed with the generalized Wilcoxon test. A multivariate Cox proportional hazard model with hierarchical forward entering was constructed to assess prognostic factors. Survival and hazard ratio (HR) probabilities were presented with $95 \%$ confidence intervals $(\mathrm{Cl})$. A P-value $<0.05$ was considered significant different.

\section{Results}

\section{Clinical characteristics}

Patients' clinical characteristics are shown in Table 1. The median age was 39.5 years old, the male to female ratio was 1.32:1. Based on the IPI score, patients were divided into the $0 \sim 2$ points group $(n=50,69.4 \%)$ and the 3-5 points group $(n=22,30.6 \%)$. According to Ann Arbor staging system, $33(45.8 \%)$ patients were stage 
I-II and $39(54.2 \%)$ patients were stage III-IV. There were no significant differences in patient characteristics between the IEAC and BEAC groups (Table 1).

Table 1

Patients' baseline demographics and clinical characteristics.

\begin{tabular}{|c|c|c|c|c|}
\hline & & $\operatorname{IEAC}(n=40)$ & $\operatorname{BEAC}(\mathrm{n}=32)$ & $P$ value \\
\hline \multirow[t]{2}{*}{ Gender } & Male & $19(48 \%)$ & $22(69 \%)$ & \multirow[t]{2}{*}{0.10} \\
\hline & Female & $21(52 \%)$ & $10(31 \%)$ & \\
\hline \multirow[t]{2}{*}{ Age } & $<40$ & $22(55 \%)$ & $18(56 \%)$ & \multirow[t]{2}{*}{0.64} \\
\hline & $>=40$ & $18(45 \%)$ & $14(44 \%)$ & \\
\hline \multirow[t]{2}{*}{ IPI score } & $0-2$ & $27(67 \%)$ & $23(72 \%)$ & \multirow[t]{2}{*}{0.80} \\
\hline & $3-5$ & 13(33\%) & $9(28 \%)$ & \\
\hline \multirow[t]{2}{*}{ Ann Arbor stage } & 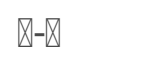 & $20(50 \%)$ & $13(41 \%)$ & \multirow[t]{2}{*}{0.48} \\
\hline & 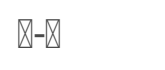 & $20(50 \%)$ & 19(59\%) & \\
\hline \multirow[t]{2}{*}{ LDH level } & $\leq 250$ & $32(80 \%)$ & $23(72 \%)$ & \multirow[t]{2}{*}{0.58} \\
\hline & $>250$ & $8(20 \%)$ & $9(28 \%)$ & \\
\hline \multirow[t]{2}{*}{ Status before ASCT } & $\mathrm{CR}$ & $27(67 \%)$ & $19(59 \%)$ & \multirow[t]{2}{*}{0.62} \\
\hline & PR & 13(33\%) & $13(41 \%)$ & \\
\hline
\end{tabular}

\section{Hematopoietic engraftment}

All patients achieved completed hematopoietic engraftment. The median time to neutrophil engraftment (> $500 / \mathrm{mm}^{3}$ ) showed no significant difference between IEAC and BEAC (11 vs 12 days, $\mathrm{P}=0.23$ ) groups. The median time of engarftment of platelets were 19.5 days (range 13 to $35 \mathrm{~d}$ ) in the IEAC group and 20 days (range 13 to $32 \mathrm{~d}$ ) in the BEAC group, still showing no difference $(P=0.53$, Table 2$)$. 
Table 2

Hematopoietic engraftment after ASCT.

\begin{tabular}{|llll|}
\hline & IEAC & BEAC & \multirow{2}{*}{ P value } \\
\cline { 1 - 3 } & median (range) & median (range) & \\
\hline $\begin{array}{l}\text { Time to neutrophils } \\
>500 \times 10^{3} / \mathrm{mm} \text { (days) }\end{array}$ & $11.0(9-27)$ & $12.0(8-24)$ & 0.23 \\
$\begin{array}{l}\text { Time to platelets } \\
>20,000 \times 10^{3} / \mathrm{mm} 3 \text { (days) }\end{array}$ & $19.5(13-35)$ & $20.0(13-32)$ & 0.53 \\
\hline
\end{tabular}

\section{Adverse Events}

The toxicities between the IEAC and the BEAC groups were shown in Table 3. The most common related adverse events (AEs) observed in all patients were febrile neutropenia (70.8\%), nausea and vomiting (48.6\%), oral mucositis $(11 \%)$, cardiac toxicity $(6.9 \%)$, veno-occlusive disease/sinusoidal obstruction syndrome (VOD/SOS, 4.2\%) and central nervus system (CNS) adverse reactions (4.2\%). IEAC group seemed to have more febrile neutropenia (77.5\%) compared to BEAC group (62.5\%), however didn't show significant difference between the two groups $(P=0.19)$. No other statistically significant extrahematological toxicities emerged [mucositis ( $12.5 \%$ vs $9.4 \%, P=0.72)$, nausea/vomiting ( $50 \%$ vs $46.9 \%, P=0.82)$ ]. The same situation was observed in cardiac toxicity, VOD/SOS and CNS reaction. Overall severe AEs (by definition of grade $\geq 3$ ) did not differ between these two groups. There was no transplant related mortality (TRM) for all patients indicating that IEAC condition regimen was well tolerated.

Table 3

Toxicities between IEAC and BEAC groups.

\begin{tabular}{|llll|}
\hline & IEAC(n= 40) & BEAC(n = 32) & P value \\
\hline Mucositisa & $5(12.5 \%)$ & $3(9.4 \%)$ & 0.73 \\
\hline Febrile neutropenia & $31(77.5 \%)$ & $20(62.5 \%)$ & 0.19 \\
\hline Nausea/vomiting & $20(50 \%)$ & $15(46.9 \%)$ & 0.82 \\
\hline Cardiac toxicity & $3(7.5 \%)$ & $2(6.3 \%)$ & 1.00 \\
\hline VOD/SOS & $1(2.5 \%)$ & $2(6.3 \%)$ & 0.58 \\
\hline CNS reactions & $2(5 \%)$ & $1(3.1 \%)$ & 1.00 \\
\hline
\end{tabular}

\section{Survival Analysis}

A total of $12(12 / 72,16.7 \%)$ patients died due to disease progression. The median follow-up time was 31 months. The median OS of IEAC group was 33.0 months (95\% confidence interval [CI], 28.50-36.00 months), 
which was longer than that of BEAC group (30.0 months, $95 \% \mathrm{Cl} 23.51-35.00$ months $)(P=0.02$, Fig. $2 A)$. Also, the median PFS between IEAC and BEAC groups were 23.0 months $(95 \% \mathrm{Cl}, 16.00-25.50$ months) and 18.0 months $(95 \% \mathrm{Cl}, 10.50-27.00$ months) respectively $(P=0.03$, Fig. $2 B)$, indicating that IEAC conditioning regimen resulted in better outcomes compared to BEAC. No matter diffuse large $B$ cell lymphoma (DLBCL) or mantle cell lymphoma (MCL), the prognosis of IEAC groups were better than that of BEAC groups (Figs. 3 and 4).

\section{Prognosis factors}

The univariate and multivariate analysis showed that lactate dehydrogenase (LDH), remission status before ASCT, AnnArbor stage, IPI score and conditioning regimens were prognostic factors relating to outcomes.

Patients with lower LDH, AnnArbor Stage and IPI score had better prognosis $(P<0.05)$, and patients achieved CR before ASCT had longer PFS $(P=0.043)$ and OS $(P=0.045)$ compared to patients with PR before ASCT. In addition, patients received IEAC conditioning regimen had longer PFS $(P=0.02)$ and $O S(P=0.03)$ than patients in BEAC group (Table 4). 
Table 4

Univariate and Multivariate analysis of factors potentially associated with survivals

\begin{tabular}{|c|c|c|c|c|c|c|c|c|}
\hline \multirow[t]{3}{*}{ Factors } & \multicolumn{4}{|l|}{ Univariate } & \multicolumn{4}{|l|}{ Multivariate } \\
\hline & \multicolumn{2}{|l|}{ OS } & \multicolumn{2}{|l|}{ PFS } & \multicolumn{2}{|l|}{ os } & \multicolumn{2}{|l|}{ PFS } \\
\hline & $\mathrm{HR}(95 \% \mathrm{Cl})$ & $\begin{array}{l}\mathrm{P} \\
\text { value }\end{array}$ & $\mathrm{HR}(95 \% \mathrm{Cl})$ & $\begin{array}{l}\mathrm{P} \\
\text { value }\end{array}$ & $\mathrm{HR}(95 \% \mathrm{Cl})$ & $\begin{array}{l}\mathrm{P} \\
\text { value }\end{array}$ & $\mathrm{HR}(95 \% \mathrm{Cl})$ & $\begin{array}{l}\mathrm{P} \\
\text { value }\end{array}$ \\
\hline \multicolumn{9}{|l|}{ Gender } \\
\hline Male(41) & 1 & \multirow[t]{2}{*}{0.080} & 1 & \multirow[t]{2}{*}{0.083} & \multirow[t]{2}{*}{ - } & & \multirow[t]{2}{*}{-} & \multirow[t]{2}{*}{-} \\
\hline Female(31) & $\begin{array}{l}0.342 \\
(0.103- \\
1.137)\end{array}$ & & $\begin{array}{l}0.346 \\
(0.104- \\
1.150)\end{array}$ & & & & & \\
\hline \multicolumn{9}{|l|}{ Age } \\
\hline$₫ 40(40)$ & 1 & \multirow[t]{2}{*}{0.888} & 1 & \multirow[t]{2}{*}{0.806} & \multirow[t]{2}{*}{-} & & \multirow[t]{2}{*}{-} & \multirow[t]{2}{*}{-} \\
\hline$\geq 40(32)$ & $\begin{array}{l}0.921 \\
(0.292- \\
2.905)\end{array}$ & & $\begin{array}{l}0.866 \\
(0.274- \\
2.733)\end{array}$ & & & & & \\
\hline \multicolumn{9}{|l|}{ IPI score } \\
\hline $0-2(50)$ & 1 & \multirow[t]{2}{*}{0.002} & 1 & \multirow[t]{2}{*}{0.001} & \multirow[t]{2}{*}{-} & & \multirow[t]{2}{*}{-} & \multirow[t]{2}{*}{-} \\
\hline $3-5(22)$ & $\begin{array}{l}8.339 \\
(2.251- \\
30.893)\end{array}$ & & $\begin{array}{l}9.350 \\
(2.505- \\
34.899)\end{array}$ & & & & & \\
\hline \multicolumn{9}{|l|}{$\begin{array}{l}\text { AnnArbor } \\
\text { stage }\end{array}$} \\
\hline$\rrbracket-\rrbracket(33)$ & 1 & \multirow[t]{2}{*}{0.049} & 1 & \multirow[t]{2}{*}{0.061} & \multirow[t]{2}{*}{ - } & & \multirow[t]{2}{*}{-} & \multirow[t]{2}{*}{-} \\
\hline$\rrbracket-\rrbracket(39)$ & $\begin{array}{l}4.591 \\
(1.005- \\
20.969)\end{array}$ & & $\begin{array}{l}4.272 \\
(0.934- \\
19.530)\end{array}$ & & & & & \\
\hline \multicolumn{9}{|l|}{ LDH level } \\
\hline$\leq 250(55)$ & 1 & \multirow{2}{*}{$<0.001$} & 1 & \multirow{2}{*}{$<.001$} & 1 & \multirow{2}{*}{$<.001$} & 1 & $<$ \\
\hline$\geq 250(17)$ & $\begin{array}{l}0.073 \\
(0.020- \\
0.273)\end{array}$ & & $\begin{array}{l}0.062 \\
(0.016- \\
0.234)\end{array}$ & & $\begin{array}{l}0.072 \\
(0.019- \\
0.269)\end{array}$ & & $\begin{array}{l}0.065 \\
(0.017- \\
0.245)\end{array}$ & 0.001 \\
\hline $\begin{array}{l}\text { Status } \\
\text { before ASCT }\end{array}$ & & & & & & & & \\
\hline $\mathrm{CR}(46)$ & 1 & 0.045 & 1 & 0.043 & - & - & - & - \\
\hline
\end{tabular}

Abbreviations: IPI, international prognostic index; LDH, lactate dehydrogenase; $C R$, complete remission; PR, partial remission; ASCT, autologous stem cell transplantation. 


\begin{tabular}{|c|c|c|c|c|c|c|c|c|}
\hline Factors & \multicolumn{4}{|l|}{ Univariate } & \multicolumn{4}{|c|}{ Multivariate } \\
\hline PR(26) & $\begin{array}{l}3.428 \\
(1.031- \\
11.402)\end{array}$ & & $\begin{array}{l}3.460 \\
(1.041- \\
11.503)\end{array}$ & & & & & \\
\hline \multicolumn{9}{|c|}{$\begin{array}{l}\text { Conditioning } \\
\text { regimen }\end{array}$} \\
\hline $\operatorname{IEAC(40)}$ & 1 & \multirow[t]{2}{*}{0.023} & 1 & \multirow[t]{2}{*}{0.034} & 1 & \multirow[t]{2}{*}{0.041} & 1 & \multirow[t]{2}{*}{0.032} \\
\hline BEAC(32) & $\begin{array}{l}3.494 \\
(0.751- \\
10.284)\end{array}$ & & $\begin{array}{l}3.216 \\
(0.666- \\
10.372)\end{array}$ & & $\begin{array}{l}3.546 \\
(0.757- \\
10.569)\end{array}$ & & $\begin{array}{l}3.843 \\
(0.550- \\
10.172)\end{array}$ & \\
\hline \multicolumn{9}{|c|}{$\begin{array}{l}\text { Pathological } \\
\text { type }\end{array}$} \\
\hline DLBCL(52) & 1 & \multirow[t]{2}{*}{0.633} & 1 & \multirow[t]{2}{*}{0.638} & \multirow[t]{2}{*}{ - } & \multirow[t]{2}{*}{-} & \multirow[t]{2}{*}{-} & \multirow[t]{2}{*}{-} \\
\hline MCL(20) & $\begin{array}{l}1.375 \\
(0.371- \\
5.091)\end{array}$ & & $\begin{array}{l}1.370 \\
(0.369- \\
5.085)\end{array}$ & & & & & \\
\hline
\end{tabular}

\section{Discussion}

HDC followed by ASCT could make patients to achieve deeper response, as a result some of them were cured. The PARMA study was the first randomized trial to demonstrate that the use of HDC followed by ASCT resulted in better prognosis compared to standard chemotherapy in patients with relapsed NHL [18-22]. Several studies demonstrated that HDC followed by ASCT as consolidation therapy for patients achieved CR after induction therapy could prolong the PFS, but not the OS [23-24]. Composed of drugs usually not employed in front-line therapy and not causing high toxicities, BEAC is generally very effective and well tolerated [15-16, 25-28].

Anthracyclines drug such as doxorubicin was commonly used to treat NHL patients. Some studies found that idarubicin was an important anthracyclines drug in lymphoma chemotherapy. Combination of idarubicin and other chemodrugs were utilized as the salvage treatment to achieve high response rate [18-19]. However, few reports demonstrated the efficacy and toxicities of conditioning regimen including idarubicin. Due to the shortage of carmustine, bendamustine and nimustine in China, we modified BEAC protocol by replacing BCNU with idarubicin and examine and evaluate its efficacy and side effects in our single center.

Our results showed that IEAC scheme was well tolerated. As expected, the most frequently observed hematologic toxicity was febrile neutropenia (70.8\%), higher than other reports [28-30], however the median time of neutrophils engarftment did not differ significantly between the IEAC and the BEAC groups. No patient experienced grade IV nausea and vomiting; grade III nausea and vomiting were observed in $50 \%$ of patients, higher than other reports. But cardiac toxicity observed in our study was $6.9 \%$, lower than other reports [31, 32]. No patient showed significant liver or kidney toxicity and no patient died due to TRM. 
For patients with NHL, IEAC produced longer PFS and OS to contemporary patients treated with BEAC, indicating superior outcomes for IEAC. Our results showed that AnnArbor stage, IPI score, LDH level, the remission status before ASCT and conditioning regimen were prognostic factors. Although it was a retrospective study, the case study was not large and included various histologic types of lymphoma, it was still possible to make some assessments of the efficacy of IEAC. Further prospective, randomized comparative clinical trials should be performed to confirm that IEAC is superior than BEAC.

\section{Conclusion}

In conclusion, IEAC prolonged the PFS and OS while didn't increase the incidence of toxicities. Furthermore, IEAC did not prolong the median time of hematopoietc engraftment. IEAC has been proven to be safe and effective in different histologic types of lymphoma and, therefore, it may be put forward for consideration.

\section{Declarations}

\section{Ethics approval and consent to participate}

Not applicable

\section{Consent for publication}

Not applicable

\section{Availability of data and material}

The data sets used and/or analyzed during the current study are available from the corresponding author on reasonable request.

\section{Competing interests}

The authors have no conflicts of interest.

\section{Funding}

The study was funded by grants 81670104 from the National Natural Science Foundation of China (NSFC).

\section{Authors' contributions}

Y.L. acquired and analyzed the data, and drafted the paper. Y.W. drafted and revised the paper. S.L., Z.C., Y.Y., Z.Z., H.Z. and H.Y. acquired and analyzed the data. Y.Z. designed the experiments. C. T. designed the experiments, interpreted the data and critically revised the paper. All authors approved all versions including the final version, and are responsible for the accuracy and integrity of all aspects of the manuscript.

\section{Acknowledgements}

Not applicable 


\section{References}

[1] Siegel RL, Miller KD, Jemal A. Cancer statistics. 2019; CA Cancer J Clin. 2019; 69(1): 7-34.

[2] Ardeshna KM, Kakouros N, Qian W, et al. Conventional second-line salvage chemotherapy regimens are not warranted in patients with malignant lymphomas who have progressive disease after first-line salvage therapy regimens. $\mathrm{Br} \mathrm{J}$ Haematol. 2005; 130: 363-372.

[3] Bierman PJ, Armitage JO. Looking back (and ahead) at salvage treatment for non-Hodgkin lymphoma. Oncology (Williston Park). 2009; 23: 619-625.

[4] Seshadri T, Kuruvilla J, Crump M, et al. Salvage therapy for relapsed/refractory diffuse large B cell lymphoma. Biol Blood Marrow Transplant. 2008; 14: 259-267.

[5] Philip T, Guglielmi C, Hagenbeek A, et al. Autologous bone marrow transplantation as compared with salvage chemotherapy in relapses of chemotherapy-sensitive non-Hodgkin's lymphoma. N Engl J Med. 1995; 333: $1540-5$.

[6] Gunnellini M, Emili R, Coaccioli S, et al. The role of autologous stem cell transplantation in the treatment of diffuse large B-cell lymphoma. Adv Hematol. 2012; 2012: 195484.

[7] Greb A, Bohlius J, Schiefer D, et al. High-dose chemotherapy with autologous stem cell transplantation in the first line treatment of aggressive non-Hodgkin lymphoma (NHL) in adults. Cochrane Database Syst Rev. 2008; 23(1): CD004024.

[8] Chen YB, Lane AA, Logan BR, et al. Impact of conditioning regimen on outcomes for patients with lymphoma undergoing high-dose therapy with autologous hematopoietic cell transplantation. Biol Blood Marrow Transplantat. 2015; 21(6): 1046-1053.

[9] Olivieri J, Mosna F, Pelosini M, et al. A comparison of the conditioning regimens BEAM and FEAM for autologous hematopoietics stem cell transplantation in lymphoma: an observational study on 1038 patients from fondazione Italiana Linfomi. Biol Blood Marrow Transplant. 2018; 24(9): 1814-1822.

[10] Villa D, Crump M, Keating A, et al. Outcome of patients with transformed indolent non-Hodgkin lymphoma referred for autologous stem-cell transplantation. Ann Oncol. 2013; 24: 1603-1609.

[11] Berber I, Erkurt MA, Nizam I, et al. Can BuCyE conditioning regimen be an alternative treatment to BEAM at autologous transplantation in malignant lymphoma patients?: a single center experience. Int J Clin Exp Med. 2015; 8: 16308-16314.

[12] Damon LE, Johnson JL, Niedzwiecki D, et al. Immunochemotherapy and autologous stem-cell transplantation for untreated patients with mantle-cell lymphoma: CALGB 59909. J Clin Oncol. 2009; 27(36): 6101-8.

[13] Visani G, Stefani PM, Capria S, et al. Bendamustine, etoposide, cytarabine, melphalan, and autologous stem cell rescue produce a 72\% 3-year PFS in resistant lymphoma. Blood. 2014; 124: 3029-3031. 
[14] Flowers CR, Costa LJ, Pasquini MC, et al. Efficacy of pharmacokinetics-directed busulfan, cyclophosphamide, and etoposide conditioning and autologous stem cell transplantation for lymphoma: comparison of a multicenter phase II study and CIBMTR outcomes. Biol Blood Marrow Transplant. 2016; 22(7): 1197-1205.

[15] Jo JC, Kang BW, Jang G, et al. BEAC or BEAM highdose chemotherapy followed by autologous stem cell transplantation in non-Hodgkin's lymphoma patients: comparative analysis of efficacy and toxicity. Ann Hematol. 2008; 87: 43-48.

[16] Robinson SP, Boumendil A, Finel $\mathrm{H}$, et al. High-dose therapy with BEAC conditioning compared to BEAM conditioning prior to autologous stem cell transplantation for non-Hodgkin lymphoma: no differences in toxicity or outcome. A matched-control study of the EBMT-Lymphoma Working Party. Bone Marrow Transplant. 2018; 53(12): 1553-1559.

[17] Engert A, Schnell R, Kupper F, et al. A phase-Il study with idarubicin, ifosfamide and VP-16 (IIVP-16) in patients with refractory or relapsed aggressive and high grade non-Hodgkin's lymphoma. Leuk Lymphoma. 1997; 24: 513-522.

[18] Abali H, Oyan B, Koc $Y$, et al. IIVP salvage regimen induces high response rates in patients with relapsed lymphoma before autologous stem cell transplantation. Am J Clin Oncol. 2005; 28(3): 264-9.

[19] Oyan B, Koc Y, Ozdemir E, et al. Ifosfamide, idarubicin, and etoposide in relapsed/refractory Hodgkin disease or non-Hodgkin lymphoma: a salvage regimen with high response rates before autologous stem cell transplantation. Biol Blood Marrow Transplant. 2005; 11(9): 688-97.

[20] Cheson B, Fisher R, Barrington S, et al. Recommendations for initial evaluation, staging and response assessment of Hodgkin and non-Hodgkin lymphoma: the Lugano classification. J Clin Oncol. 2014; 32: 30593068 .

[21] Kaplan EL, Meier P. Nonparametric estimation from incomplete observation. J Am Stat Assoc. 1958; 53: 457-481.

[22] Galieni P, Troiani E, Bigazzi C, et al. Modified BEAM as conditioning regimen for lymphoma patients undergoing autologous hematopoietic stem cell transplantation. Bone Marrow Transplant. 2018; 53(1): 91-93.

[23] Haioun C, Lepage E, Gisselbrecht C, et al. Survival benefit of high-dose therapy in poor-risk aggressive non-Hodgkin's lymphoma: final analysis of the prospective LNH87-2 protocol-a grouped'Etude des lymphomes de l'Adulte study. J Clin Oncol. 2000; 18: 3025-3030.

[24] Chiappella A, Martelli M, Angelucci E, et al. Rituximab-dose-dense chemotherapy with or without highdose chemotherapy plus autologous stem-cell transplantation in high-risk diffuse large B-cell lymphoma (DLCL04): final results of a multicentre, open-label, randomised,controlled, phase 3 study. Lancet Oncol. 2017; 18: 1076-1088. 
[25] Salar A, Sierra J, Gandarillas M, et al. Autologous stem cell transplantation for clinically aggressive nonHodgkin's lymphoma: the role of preparative regimens. Bone Marrow Transplant. 2001; 27: 405-412.

[26] Shi Y, Liu P, Zhou S, et al. Comparison of CBV, BEAM and BEAC high-dose chemotherapy followed by autologous hematopoietic stem cell transplantation in non-Hodgkin lymphoma: Efficacy and toxicity. Asia Pac J Clin Oncol. 2017; 13(5): e423-e429.

[27] Geisler CH, Kolstad A, Laurell A, et al. Nordic MCL2 trial update: six-year follow-up after intensive immunochemotherapy for untreated mantle cell lymphoma followed by BEAM or BEAC + autologous stemcell support: still very long survival but late relapses do occur. Br J Haematol. 2012; 158(3): 355-62.

[28] Sakellari I, Gavriilaki E, Bouziana S, et al. BEAC (carmustine, etoposide, cytarabine, and cyclophosphamide) in autologous hematopoietic cell transplantation: a safe and effective alternative conditioning regimen for Hodgkin and non-Hodgkin lymphoma. Bone Marrow Transplant. 2019; 54(6): 921923.

[29] T. Kuittinen1, E. Jantunen,E. Vanninen,et al. Cardiac effects within 3 months of BEAC high-dose therapy in non-Hodgkin's lymphoma patients undergoing autologous stem cell transplantation. Eur J Haematol 2006; 77: $120-127$.

[30] Derenzini E, Musuraca G, Fanti S, et al. Pretransplantation positron emission tomography scan is the main predictor of autologous stem cell transplantation outcome in aggressive B-cell non-Hodgkin lymphoma. Cancer. 2008; 113: 2496-503.

[31] Sauter CS, Matasar MJ, Meikle J, et al. Prognostic value of FDG-PET prior to autologous stem cell transplantation for relapsed and refractory diffuse large B-cell lymphoma. Blood. 2015; 125: 2579-81.

[32] Isidori A, Christofides A, Visani G. Novel regimens prior to autologous stem cell transplantation for the management of adults with relapsed/refractory non-Hodgkin lymphoma and Hodgkin lymphoma: alternatives to BEAM conditioning. Leuk Lymphoma. 2016; 57(11): 2499-509.

\section{Figures}


Figure 1

\section{2 patients were included for initial registration and assessed for eligibility}

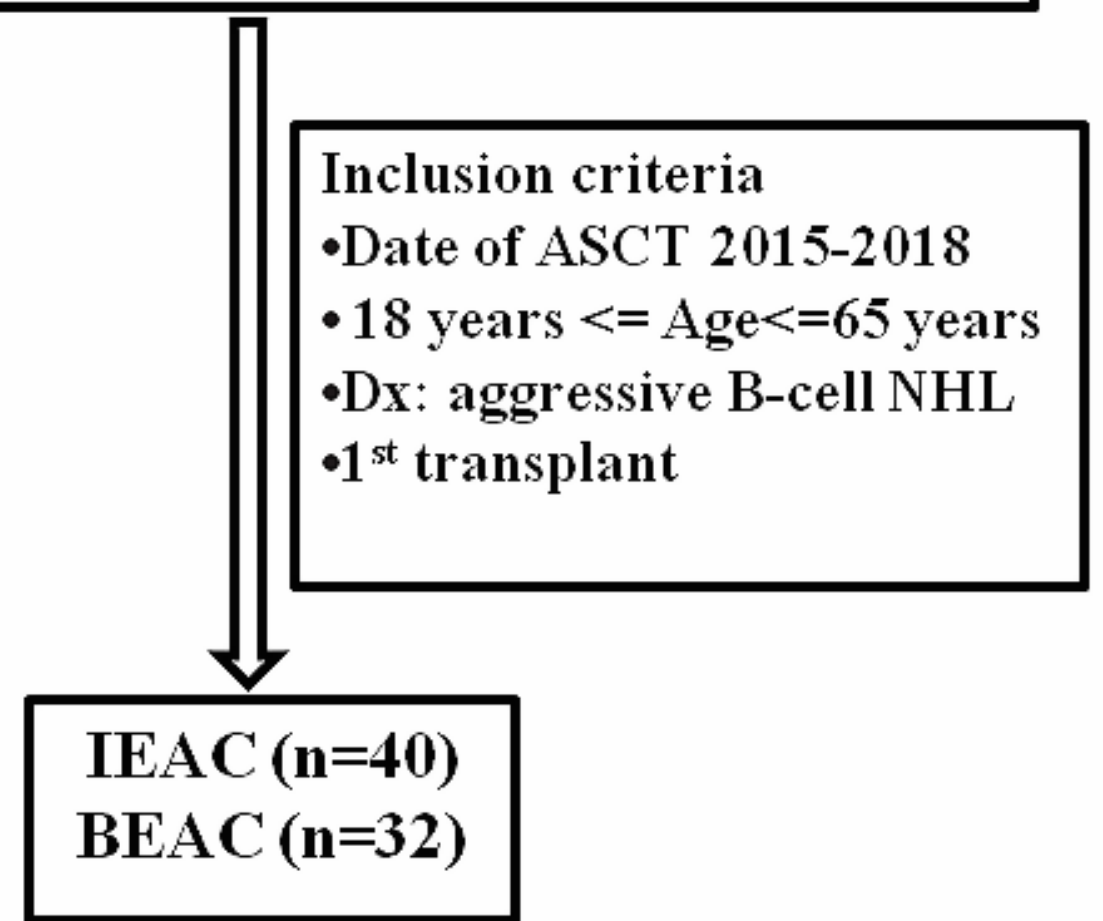

Figure 1

Study design

Figure 2
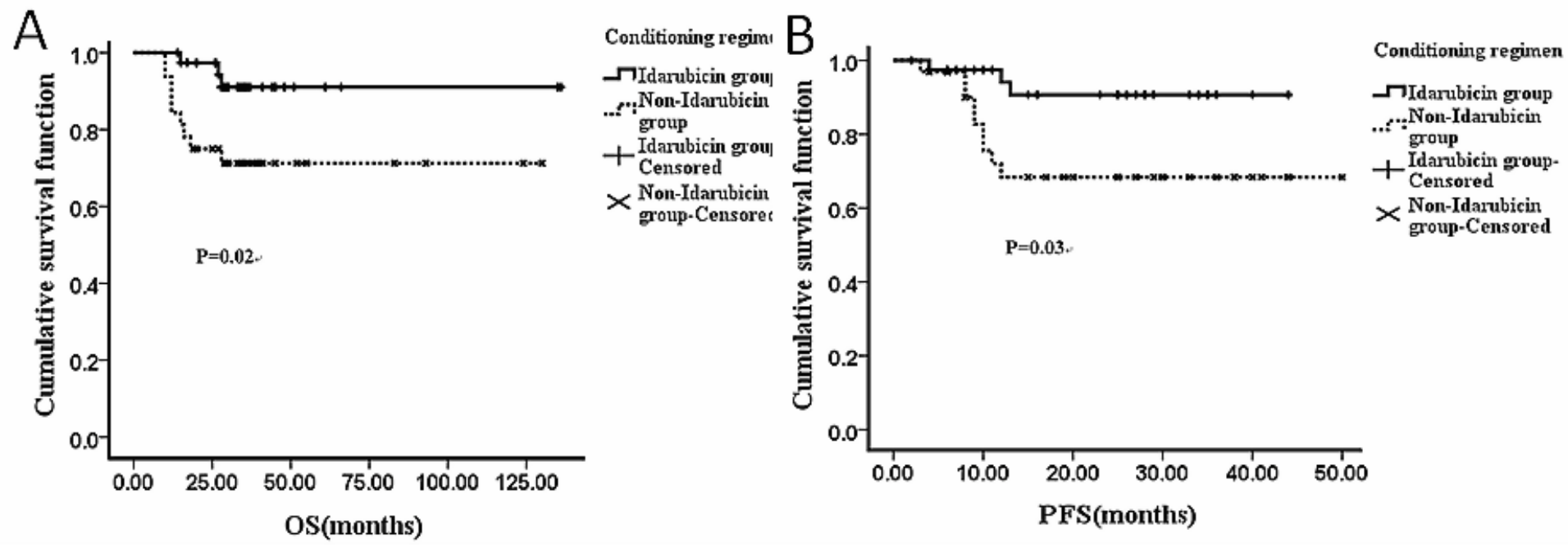

Figure 2

OS and PFS after high-dose chemotherapy followed by ASCT conditioned with IEAC or BEAC. 
Figure 3

A

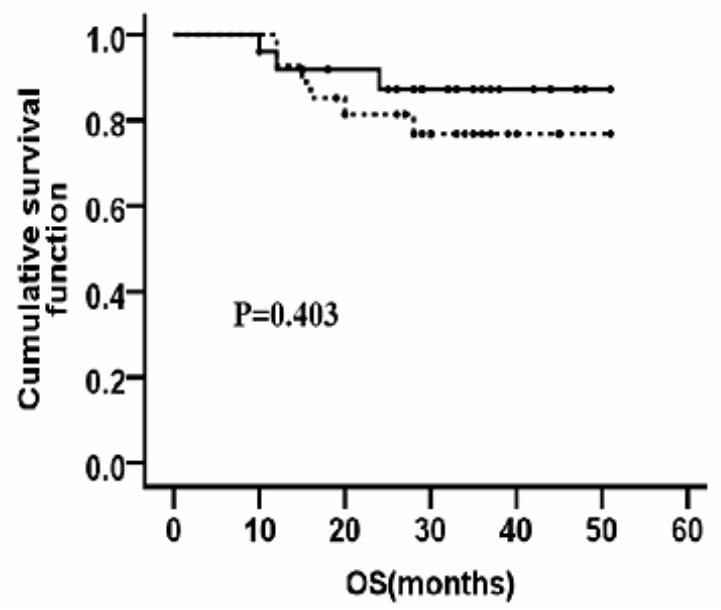

B

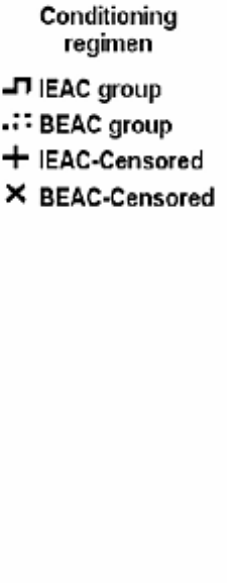

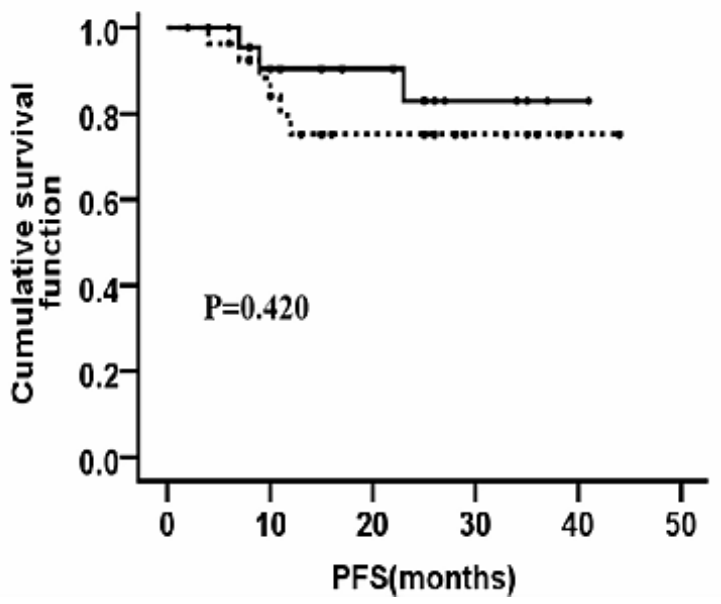

Figure 3

OS and PFS of DLBCL patients in IEAC group were longer than that in BEAC group.

\section{Figure 4}

A

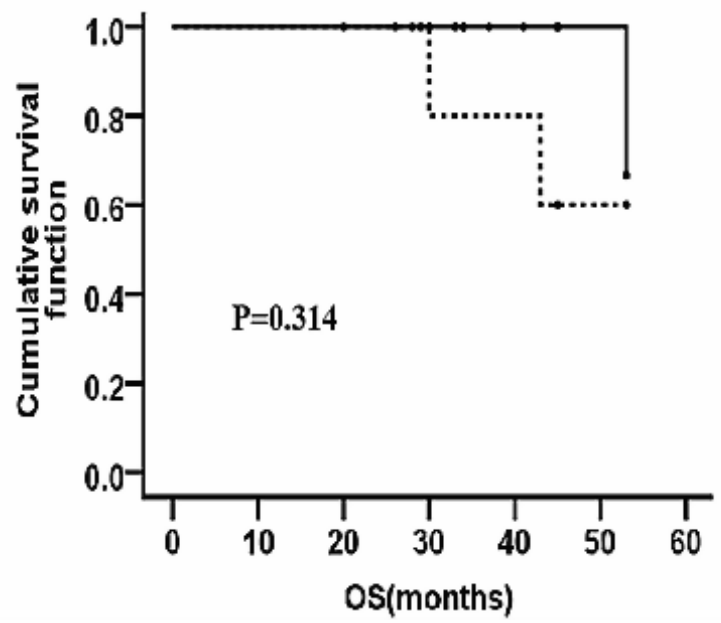

B

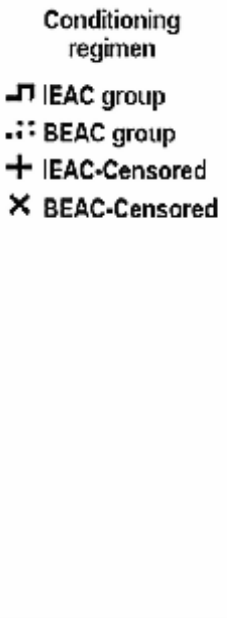

Conditioning regimen

तIEAC group $\therefore$ BEAC group + IEAC-Censored

$X$ BEAC-Censored

Figure 4

OS and PFS of MCL patients in IEAC group were longer than that in BEAC group. 